\title{
LINKING ACADEMIC AND LABOR TRAINING IN FINALIST GRADUATE SUBJECTS: A STRATEGY TO IMPROVE STUDENTS TRANSVERSAL COMPETENCES
}

\author{
J. Ibáñez Civera, N. Laguarda Miró, L. Gil Sánchez, E. García Breijo, C.A. Olguín \\ Pinatti, J. Monreal Trigo, J.M. Terrés Haro \\ Universitat Politècnica de València (SPAIN)
}

\begin{abstract}
In the current presentation we propose the integration of training for employment in the last subjects of university degrees. Specifically, for this case, contents and activities of the elective subject "Organic Electronic and Processes in Electronic Design" are reformulated. This subject is included in the Degree in Industrial Electronics and Automation at the Universitat Politècnica de València (UPV). The aim of this proposal is to include training for employment (or external practices) and how to deal with the initial contacts with the destination work centre.
\end{abstract}

Keywords: training for employment, technology, teaching organization.

\section{INTRODUCTION}

When the students of a bachelor degree are finishing their studies, in the last semester, they see the end of a cycle of their life dedicated to the formation in the degree they have chosen. Before them a range of possibilities opens. These possibilities will give meaning to this training and will continue to prepare them, in the end, be excellent professionals. Almost all the students consider the possibility of doing internships in a company (Table I) while preparing and completing their Final Degree Project (TFG).

Most of the students are convinced that they need to specialize in their matter by doing a master study. (According to the report on job placement of graduates at the Universitat Politècnica de València 2016/2017 [1], 27.2\% of students that finish the Degree in Industrial Electronics and Automation at the UPV, continue with a master study). A part, perhaps the least significant, decides to look for a job and try to make it compatible with the follow-up of specialization studies. The truth is that, with all the training received and even after the incorporation into the study plan of training in skills, there are gaps in the strategies and tools necessary to make a correct approach to the world of work. According to the same report [1], although $50 \%$ of the students of the degree combine their studies with a job, only $55.3 \%$ of them do it in an occupation related to their studies.

In short, there is almost a $20 \%$ of students who at the end of their undergraduate studies will look for a first job and almost a $25 \%$ more that, although they already have a paid job, this does not adapt to the profile of their degree or at the academic and professional level of their studies.

Almost all universities have specific employment services, with practices management for students and postgraduates. These services do an excellent job, but, like many of the services that the university offers to the students, they are little known because, in their brief stay at the university, students doesn't have enough time to dedicate to their studies, prepare their exams, jobs, etc.

This proposal focuses on a specific subject of the Degree in Industrial Electronics and Automation. This degree is taught in the Design Engineering School (ETSID) at the UPV.

The subject, "Organic Electronics and Processes in Electronic Design", is taught in the last semester of the degree for 10 weeks, with 4.5 hours of classroom teaching per week (4.5 ECTS).

This subject is an elective course and it is taught in a group of 25 students approximately. As it is a small group, it allows a more direct student-teacher interaction and a better follow-up of the students' activities. 
Table 1. Students in business practice (electronics)

\begin{tabular}{c|c|c}
\hline \hline Academic course & number of practices & number of students \\
\hline $2015-2016$ & 165 & 104 \\
\hline $2016-2017$ & 146 & 97 \\
\hline $2017-2018$ & 254 & 155 \\
\hline \hline
\end{tabular}

\section{METHODOLOGY}

The final objective of this proposal is to introduce an employment training didactic unit in the program of the subject. The placement of this unit must be consistent with the rest of the contents and must not suppose a rupture of the subject's topic line.

The contents are organized in 10 teaching units (Table 2), of diverse length. In addition, activities related to transversal training are also carried out. The subject develops the transversal competence number 8: effective communication [2] [3]. For this reason, students make two presentations during the semester (units 7 and 9).

The didactic unit 10 has been introduced as a last step before finishing the teaching activities and aims to give some keys to finding a job suitable to the training received.

Table 2. Contents proposal

\begin{tabular}{c|l}
\hline \hline Unit & \multicolumn{1}{c}{ Contents } \\
\hline 1 & Integrated Circuits. Monolithic \\
\hline 2 & Integrated Circuits. Hybrid \\
\hline 3 & Printed Circuit Technology \\
\hline 4 & Printed Circuit Design \\
\hline 5 & Organic Electronics \\
\hline 6 & Final Degree Project (FDP) Contents \\
\hline 7 & FDP Objectives (students' presentation) \\
\hline 8 & Full prototype design \\
\hline 9 & Students FDP Presentation Training \\
\hline 10 & Searching for a first job strategies \\
\hline \hline
\end{tabular}

\subsection{The "searching for a first job strategies" unit}

With the placement of the didactic unit in the subject has been decided, the proposal of contents and methodology to be used is carried out.

The proposal is made according to the contents of the employment training courses offered by the Integrated Employment Service of the UPV, which has the materials and specialized personnel to teach this type of seminars.

\subsubsection{Contents}

The contents to be developed in the sessions are divided into the following sections:

- Define the student's employment goal

It is important that the students are able to put on a piece of paper their final expectations of employment. Through questionnaires that allow them to reflect on their interests when choosing a job, they can establish the profile of their "ideal company". 
- Self-Identify knowledge and skills

In this section, students must be able to define themselves and their abilities. Also their competences, both specific and transversal. They must overcome the barrier of not knowing what to say about themselves.

- Investigating the job market and companies that may be interesting for the students' objectives.

When the students already know what their ideal job is and what they can offer, they can choose the companies fitting to their aspirations. Businesses in the Valencian Community are mainly small and medium-sized companies where the Engineer's role is fundamental, leading the $R+D+I$ departments and the quality and maintenance processes. In the databases of the University there are directories of companies that have collaborated receiving trainees, as well as in employment programs launched by the UPV. These companies are a way for the students a good first place to show themselves.

- Tools for job search

Letters of motivation and curriculum vitae are the first contact with the company in which they want to work, therefore, they are extremely important documents that must not be left to chance. The contents of these important documents will be debated and discussed with the students.

The job interview. When a company requests a personal interview it is because it has positive expectations regarding the future employee. The interview will confirm these expectations if it is coherent and properly prepared. Therefore, job interviews will be worked in one of the proposed didactic units.

\subsubsection{Methodology}

An active methodology will be followed, based on the students' participation in preparing their own curricula and debating the skills and competences acquired in the studies, as well as the identification of the social and personal skills that can influence in a selection process to cover a qualified job. We have materials prepared by the Integrated Employment Service (SIE) that meet all the above requirements.

\subsubsection{Evaluation}

The evaluation of this didactic unit consists in the delivery of a letter of motivation to access a job in a company of the student's choice. The motivation letter will be qualified by the staff of the SIE and then returned to each student with the necessary observations.

\section{RESULTS}

The proposal will start working during the 2018-2019 academic year. The students will fill out a survey with their current situation and future plans allowing us to know aspects such as:

- Employment situation

○ Employed

- Employee in public administration

- Self-employment

○ Looking for a job

- Intention to take a master's degree

- Intention to carry out internships

- Intention to study or develop an internship abroad

They will also be asked for written authorization to use their contact information to be able to track their situation 1, 3 and 6 months after obtaining the degree.

This information will be crossed with that of the global students of the degree, quantifying the good effects of the presented proposal. 
An improvement in the employability of the group of students who have received specific training is expected. An improvement in the quality of the job obtained is also expected, improving the ratio of students who manage to work in positions related to their studies.

\section{CONCLUSIONS}

The authors propose the introduction of a didactic unit in the subject "Organic Electronics and Processes in Electronic Design" aimed to provide students with strategies that help them when searching quality employment related to their academic training. Finally, the didactic proposal and the procedure to verify the results by following up with the students' progress are established.

\section{ACKNOWLEDGEMENTS}

The authors are grateful for the collaboration of Elena Grimalt, ETSID internship technician, for the data provided and Malak Kubessi, Head of Guidance, Training and Employment of the UPV's Integrated Employment Service, for their participation in the inception and implementation of this didactic proposal.

\section{REFERENCES}

[1] Servicio Integrado de Empleo. "Informe de inserción laboral de los titulados y tituladas de la Universitat Politècnica de València. 2016/2017".

http://www.upv.es/contenidos/SIEOBS/menu_urlc.html?/contenidos/SIEOBS/infoweb/sieobs/info/ U0769756.pdf

[2] VILLA, A. y POBLETE, M. "Aprendizaje basado en competencias. Una propuesta para la evaluación de las competencias genéricas". Ediciones Mensajero. Bilbao. 2007

[3] UPV. Competencia transversal comunicación eficaz.

http://www.upv.es/contenidos/COMPTRAN/info/955128normalc.html 